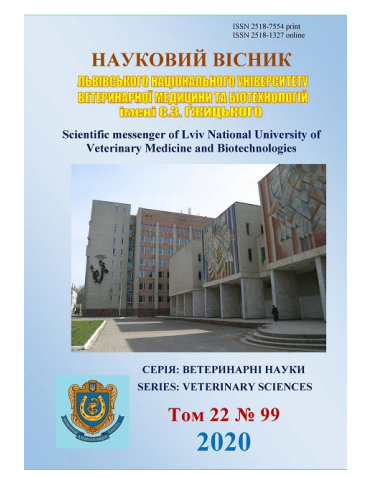

\author{
Науковий вісник Дьвівського національного університету \\ ветеринарної медицини та біотехнодогій імені С.3. Гжицыкого. \\ Серія: Ветеринарні науки \\ Scientific Messenger of Lviv National University \\ of Veterinary Medicine and Biotechnologies. \\ Series: Veterinary sciences
}

\title{
Pathomorphological characteristics of viral hemorrhagic disease of rabbits
}

\author{
S. S. Zaika, L. V. Bezditko, S. V. Guralska, T. F. Kot, Z. V. Khomenko \\ Polissia National University, Zhytomyr, Ukraine \\ Article info \\ Received 14.09.2020 \\ Received in revised form \\ 12.10.2020 \\ Zaika, S. S., Bezditko, L. V., Guralska, S. V., Kot, T. F., \& Khomenko, Z. V. (2020). \\ Pathomorphological characteristics of viral hemorrhagic disease of rabbits. Scientific Messenger of \\ Lviv National University of Veterinary Medicine and Biotechnologies. Series: Veterinary sciences, \\ 22(99), 148-154. doi: $10.32718 /$ nvlvet 9922
}

Accepted 13.10.2020

Polissia National University, Stary Boulevard, 7, Zhytomyr, 10008, Ukraine.

Tel.: +38-097-890-50-35

E-mail: lana_zaika@ukr.net
The dead animals have a pathomorphological picture with a brightly expressed hemorrhagic diathesis, in many organs there is venous stasis. Blood does not clot for several hours, and at autopsy of organs (heart, lungs, liver, kidneys) it is poured in significant amounts into the body cavity. Macroscopically, the most significant changes are observed in the respiratory system. The lungs are blood-filled, intensely swollen and unevenly colored, have a grayish-pink color with single or multiple spotted and spotted hemorrhages under the pleura. Red or almost colorless liquid flows down from the incision surface, foamy exudate is released from the bronchi when pressed on. There are no patterns in the localization of pathomorphological changes in any part of the lungs (apical, cardiac, diaphragmatic): all parts are damaged at once, or mainly in one or another part. The walls of the trachea, nasal cavities, to a lesser extent the larynx are distinctly hemorrhagic. Their red color is more often caused by venous hyperemia. The lumen of the trachea and larynx is filled with red or colorless foamy fluid. Changes in the liver are constant, but not always the same type and are due to the degree of its blood supply, which causes a change in color, amount and consistency. In the first hours after the death of the animal, the liver is usually completely blood-filled, enlarged, easily torn, has a reddish-brown color with a yellowish tinge in the central parts of the lobes. The capillary network of the body looks like red streaks and dots of irregular shape. Spotted hemorrhages are sometimes observed under the capsule of the organ. The gallbladder contains some bile, its mucous is rough, a bit exfoliated. The spleen is increased in size by 1.5-3 times, swollen, dark cherry in color with a typical purple tinge. The kidneys are completely blood-filled, reddish-brown and increased in several times. The thymus is slightly reddened, often with multiple spotted or spotted hemorrhages in the chest. Lymph nodes are pulpy, grayish-pink, rarely red, not significantly changed in size. The heart (especially its right half) is filled with a large amount of black and red blood, increased in size, the walls of the ventricles are stretched, thin, have flabby consistency. Multiple spotted and spotted hemorrhages under the epicardium and endocardium are common. Changes in the gastrointestinal tract characterize catarrhal (rarely catarrhal-hemorrhagic) inflammation, sometimes hemorrhage in the duodenum and rectum, exfoliation of the gastric mucosa. In the form of hemorrhage, pathological and anatomical changes are found in the uterus and adrenal glands, in the form of congestive hyperemia - in the genitals, goiter, brain.

Key words: rabbits, hemorrhagic disease, lungs, liver, spleen, ovary, fallopian tube.

\section{Патоморфологічна характеристика вірусної геморагічної хвороби кролів}

\author{
С. С. Заїка, Л. В. Бездітко, С. В. Гуральська, Т. Ф. Кот, З. В. Хоменко
}

Поліський начіональний університет, м. Житомир, Україна

\footnotetext{
У загиблих тварин розвивається яскрава, з вираженим геморагічним діатезом патоморфологічна картина, у багатьох органах спостерігається венозний застій. Кров не згортається протягом декількох годин, а при розтині органів (серие, легені, печінка, нирки) виливається в великих обсягах в порожнину тіла. Макроскопічно найбільш значні зміни спостерігаються в органах дихання. Легені кровонаповнені, інтенсивно набряклі і нерівномірно забарвлені, мають сірувато-рожевий колір з поодинокими або множинними крапковими і плямистими крововиливами під плеврою. 3 поверхні їх розрізу стікає червона або майже безбарвна рідина, з
} 
бронхів при натисканні виділяється пінистий ексудат. Закономірностей в локалізації патоморфологічних змін в будь-якій частиі легень (верхівкова, серцева, діафрагмальна) немає: уражуються всі частки відразу, або переважно та чи інша частина. Стінки трахеї, носових порожнин, в меншій ступені гортані різко геморагічні. Їх червоний колір частіше обумовлює венозна гіперемія. Просвіт трахеї $і$ гортані заповнює червона або безбарвна піниста рідина. Зміни в печінці постійні, але не завжди однотипові $i$ обумовлені ступенем ї̈ кровонаповнення, щуо викликає зміна кольору, об'єму і консистениії. У перші години після загибелі тварини печінка зазвичай кровонаповнена, збільшена в об'ємі, легко рветься, має червонувато-коричневий колір з жовтуватим відтінком в центральних ділянках часток. Капілярна мережа органу має вигляд червоних рисок $і$ крапок неправильної форми. Іноді під капсулою органа спостерігали крапчасті геморагіі. Жовчний міхур містить трохи жовчі, його слизова шорстка, трохи відшаровувалася. Селезінка в 1,5-3 рази збільшена в об'ємі, набрякла, темно-вишневого кольору з характерним фіолетовим відтінком. Нирки різко кровонаповнені, червоно-коричневого кольору $і$ збільшені в кілька разів. Тимус злегка почервонілий, нерідко з множинними крапковими або плямистими крововиливами в грудній частині. Лімфатичні вузли соковиті, сірувато-рожевого, рідие червоного кольору, в розмірах істотно не змінені. Серце (особливо його права половина) заповнене великим об'ємом чорно-червоної крові, збільшене в об'ємі, стінки шлуночків розтягнуті, витончені, мали в'ялу консистенцію. Часто зустрічаються множинні крапчасті і плямисті крововиливи під епі- і ендокардом. Зміни в шлунково-кишковому тракті характеризують катаральне (рідше катарально-геморагічне) запалення, іноді крововиливи в дванадиятипалій і прямій кишках, відшарування слизової шлунка. У формі геморагії патолого-анатомічні зміни знаходяться в матці і надниркових залозах, у вигляді застійної гіперемї - в статевих органах, зобній залозі, головному мозку.

Ключові слова: кролі, геморагічна хвороба, легені, печінка, селезінка, яєчник, маткова труба.

\section{Ветуп}

Серед різноманіття видів тварин помітне місце, як в дикій природі, так і в сільському господарстві займають кролики. 3 давніх часів вони приносять людині величезну користь: дають м'ясо, шкурки, пух, служать об'єктами полювання, а також є продуцентами біологічних препаратів для медицини та ветеринарії.

В Україні найбільш актуальною проблемою в патології кролів слід вважати вірусну геморагічну хворобу (ВГХК). Вона завдає значних економічних збитків, які складаються $з$ летальності тварин, i, отже, 3 недоотримання м'яса і шкурок, а також із значних матеріальних витрат на заходи боротьби і профілактики. Летальність від ВГХК становить 90-100\% (Zharov, 2000; Shevchenko \& Shevchenko, 2000).

Актуальність теми. Вивченню вірусної геморагічної хвороби кролів (ВГХК) присвячено чималу кількість досліджень, в яких, в основному, висвітлені питання етіології, епізоотології, серологічної і вірусологічної діагностики, заходів по боротьбі і профілактиці з хворобою (Mitro \& Krauss, 1993; O'Keefe et al., 1998; Puggioni \& Cavadini, 2013). Патоморфології при даній хворобі присвячено незначну кількість робіт, в основному - зарубіжних (Mouss et al., 1992; Cooke \& Fenner, 2002).

До сьогоднішнього дня залишається відкритим питання про патогенез і причини такого швидкого настання смерті при ВГХК. Деякі автори вважають основною ланкою патогенезу ураження судин, а ураження інших органів його наслідком (Korniyenko et al., 2003; Farnos et al., 2007). Інші вважають судинні порушення вторинними і викликаними дисфункцією печінки (Le Gall-Recule et al., 2003; Delibes-Mateos et al., 2007; 2008; Dalton et al., 2014; Serdyukov \& Myrs'ka, 2014).

Отже, вивчення патоморфології вірусної геморагічної хвороби кроликів слід вважати наукової стороною актуального завдання сучасного кролівництва.

Метою наших досліджень було вивчити патоморфологію вірусної геморагічної хвороби кролів. Для досягнення мети були поставлені такі завдання: 1) вивчити патоморфологію при спонтанному виникненні хвороби; 2) доповнити критерії диференційної діагностики вірусної геморагічної хвороби кролів. Тобто перед нами стояло завдання описати найбільш характерні патоморфологічні зміни вірусної геморагічної хвороби кролів (ВГХК), які дозволять встановити діагноз в перший день загибелі.

\section{Матеріал і методи досліджень}

Поставлені завдання були вирішені шляхом дослідження патологічного матеріалу, взятого при спонтанному виникненні вірусної геморагічної хвороби кроликів.

Матеріал надходив на кафедру анатомії і гістології Поліського національного університету з підсобного господарства приватного сектора смт. Черняхів, Черняхівського району, Житомирської області в період епізоотії.

Діагноз на вірусну геморагічну хворобу кролів встановлювали на підставі епізоотологічних даних, клінічних ознак, картини патологоанатомічного розтину та гістологічних досліджень.

Патологоанатомічний розтин здійснювали за методом Шора з повною евісцерацією органів (Bancroft et al., 2013). Для гістологічного дослідження брали шматочки печінки та селезінки, які фіксували в 10 \%му водному розчині нейтрального формаліну. Основна частина матеріалу була залита в парафін, потім 3 цих блоків на санному мікротомі МC-2 виготовляли гістологічні зрізи. При фарбуванні зрізів застосовували загальноприйняті методики (Horalskyi et al., 2005). Дослідження проводили за допомогою світлових мікроскопів МБС-10, Micros MC-50. Мікрофотографування гістологічних препаратів здійснювали за допомогою відеокамери САМ V 200, вмонтованої у мікроскоп Micros MC-50 і підключеної до персонального комп'ютера.

\section{Результати та їх обговорення}

Незважаючи на деякі відмінності в деталях, картина розтину у більшості кролів характеризувалась певною сталістю.

Трупи кролів були добре розвинені і вгодовані. У ряді випадків вони лежали на правому боці з витягну- 
тими кінцівками, шия і голова повернені вліво і назад. В інших випадках вони лежали на грудях, підібравши під себе передні кінцівки, задня частина тіла витягнута назад і повернута вправо.

Шерсть, як правило, гладка або дещо скуйовджена, злегка блискуча, слабко утримувалась в волосяних фолікулах. Природні отвори чисті, сухі. Іноді шерсть біля носових ходів була забруднена кров'ю або серозним ексудатом (рис. 1).

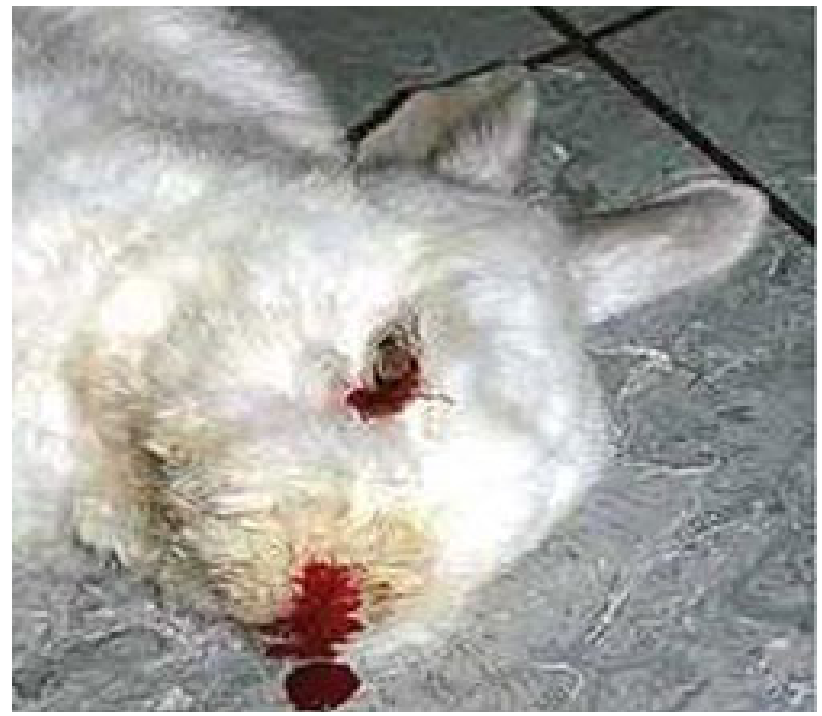

Рис. 1. Виділення геморагічного ексудату з носової порожнини при вірусній геморагічній хворобі у загиблого кроля

Носова порожнина: слизова оболонка забарвлена від світло-рожевого до темно-червоного кольору, 3 чітко видимою мережею гіперемійованих судин. Вона всіяна геморагіями, набрякла, іноді драглиста внаслідок інфільтрації ії серозним ексудатом. Нерідко поверхня слизової оболонки вкрита рідким, кров'яним, в деяких випадках 3 домішками слизу вмістом, при видаленні якого виявляється набрякла поверхня, яка сильно гіперемійована і всіяна крововиливами різної величини (рис. 2).

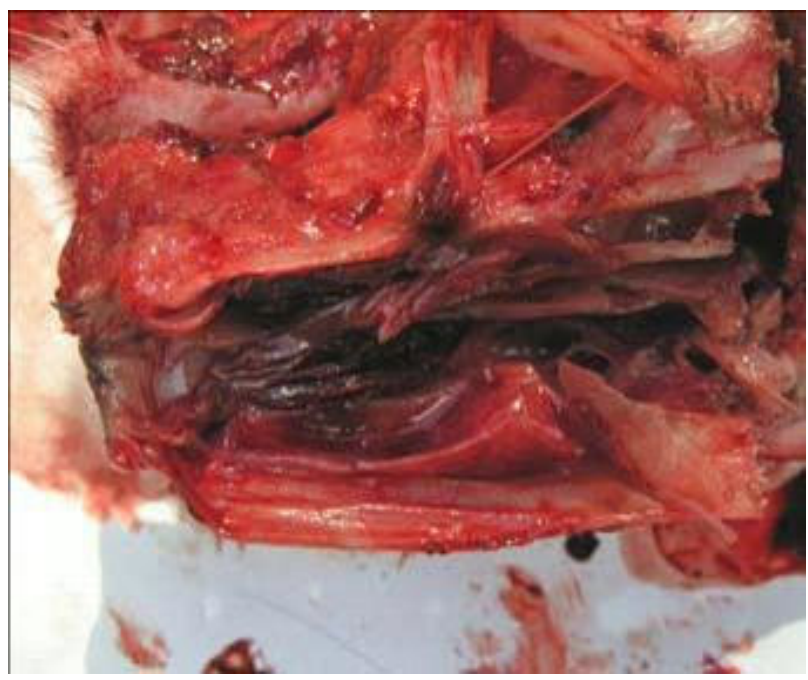

Рис. 2. Носова порожнина.

Набряк і гіперемія слизової оболонки
У ряді випадків видимі зміни слизової оболонки не виявляли. Слизова оболонка гортані набрякла, гіперемійована, іноді була вкрита крапчастими крововиливами. Слизова оболонка трахеї набрякла і дифузно гіперемійована, від світло- до темно-червоного кольору. Добре видно дрібну мережу налитих кров'ю судин. Найбільш сильно гіперемія виражена між кільцями трахеї.

Серце: міокард в'ялий, блідо-коричневого кольору. Судини сильно ін'єковані. Передсердя темновишневого, іноді - чорного кольору, їх стінки напружені, кровонаповнені, часто видно крововиливи під епікардом. Вони мають вигляд темно-червоних або чорних крапок, смуг i плям, розташованих окремо, групами або майже суцільно по всьому передсердю, уздовж вінцевих судин або на значній частині поверхні серця. При цьому в порожнині перикарда виявлявся ексудат від рожевого до темно-червоного (дещо) кольору, нерідко в значній кількості. Під ендокардом в окремих випадках виявляли крапчасті і смугасті чорно-червоні геморагії. У порожнинах серця кров погано згорнулася, ії згустки пухкі, легко рвалися.

Тимус набряклий, у молодих тварин усіяний крапчастими або великими розлитими крововиливами, у дорослих (при його наявності) міг бути без виражених змін.

Селезінка: від темно-червоного до темнофіолетового кольору з синюватим відтінком, збільшена в 1,5-3 рази, кровонаповнена, краї сильно заокруглені, при розрізі не сходились, капсула напружена, пульпа соковита, давала значний зішкріб.

3 поверхні розрізу стікала темна густа кров'яниста рідина. Трабекули і фолікули завуальовані набряклою пульпою. Іноді спостерігали незначне збільшення i розм'якшення органу, малюнок при цьому, як правило, згладжений. Часто під капсулою виявляли крововиливи різного розміру. У кроленят у віці до трьохчотирьох місяців і у частини дорослих особин (що узгоджується $з$ даними Le Gall-Recule, 2003) селезінка звичайного розміру, блідо забарвлена в рожевокоричневий з синім відтінком колір, в'яла, дає незначний зішкріб з розрізу.

По тяжкості, постійності і діагностичній значимості гістологічних змін, органи можна розташувати наступним чином: печінка, органи дихання, нирки, селезінка, серце, головний мозок, тимус, інші органи. У загиблих тварин печінка уражається в 100 \% випадків.

В селезінці спостерігається практично повна відсутність формених елементів крові, яскраво виражений набряк ретикулярного каркасу (рис. 3, 4). Міокард знаходиться в стані зернистої дистрофії, серцеві судини кровонаповнені, сполучна тканина набрякла, іноді пронизана еритроцитами.

Легені: колір від рожевого до темно-червоного i вишневого. Видно чергування рожевих i темночервоних ділянок. Консистенція в'яла, при взятті пінцетом легені легко рвуться. Шматочки легень в воді важко плавали, а деякі тонули (з найтемніших ділянок). 


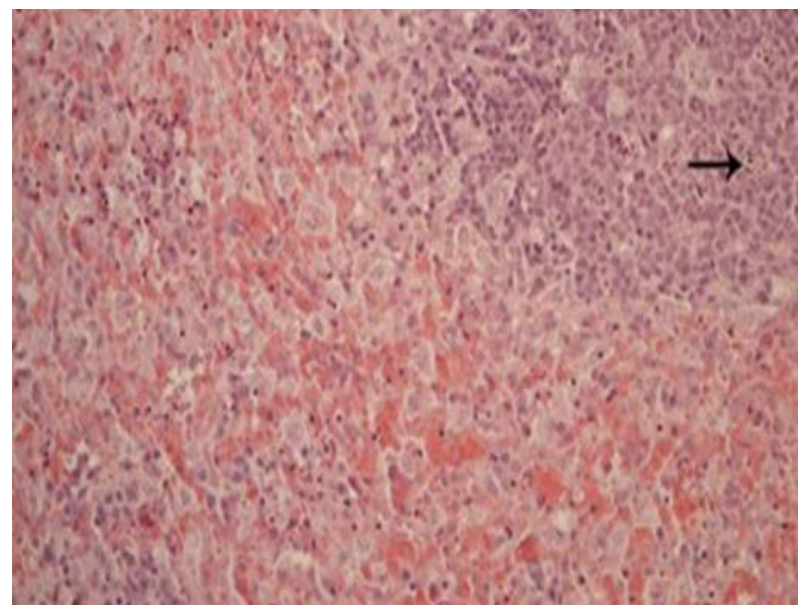

Рис. 3. Фрагмент мікроскопічної будови селезінки кроля, загиблого від вірусної геморагічної хвороби (стрілкою показано гіперплазію макрофагів в червоній пульпі). Гематоксилін Ерліха та еозин. Х 200

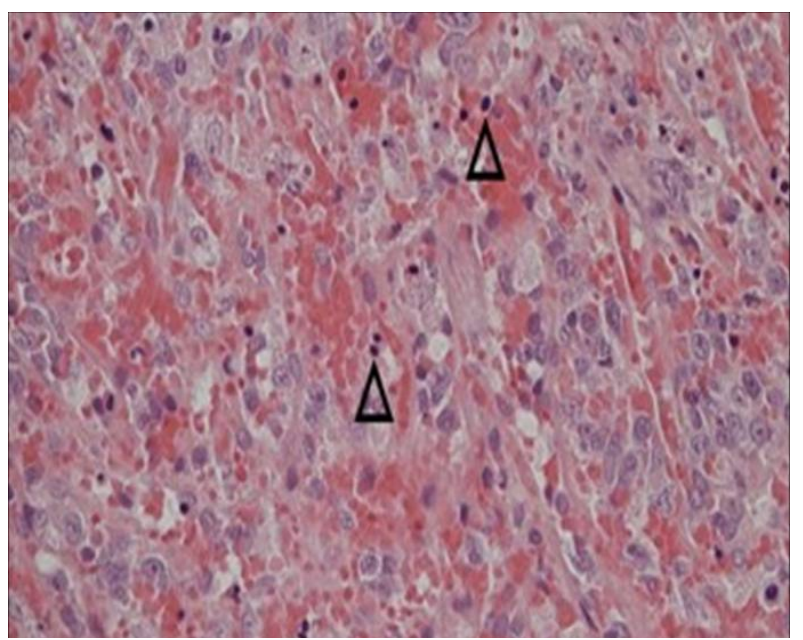

Рис. 4. Фрагмент мікроскопічної будови селезінки кроля, загиблого від вірусної геморагічної хвороби (конусами вказані пікнотичні клітини). Гематоксилін Ерліха та еозин. X 400

3 розрізу стікав кров'янистий пінистий ексудат. 3 розширених венозних судин витікала темна кров. Крапчасті, плямисті і смугасті, темно-червоні геморагії зустрічалися як під плеврою, так і в глибині паренхіми органу. Часто спостерігалось явище серозногеморагічної пневмонії (рис. 5).

Середостінні лімфатичні вузли збільшені, розм'якшені, сіро-червоного або темно-червоного кольору, на розрізі сіро-червоні, краї розрізу не сходяться, поверхня розрізу опукла, з неї стікала каламутна червона рідина. Підщелепові, передлопаткові, пахові, мезентеріальні лімфатичні вузли незначно збільшені, з розрізу стікала прозора світла рідина.

Діафрагма: сухожильна частина світло-сіра, гладенька, блискуча, м'язова частина - від блідо-рожевого до темно-червоного кольору, іноді на ній виявляли ділянки гіперемії і крововиливів. Малюнок м'язових волокон виражений.

Підшлункова залоза дещо збільшена і почервоніла, соковита, дольчаста, пружна.

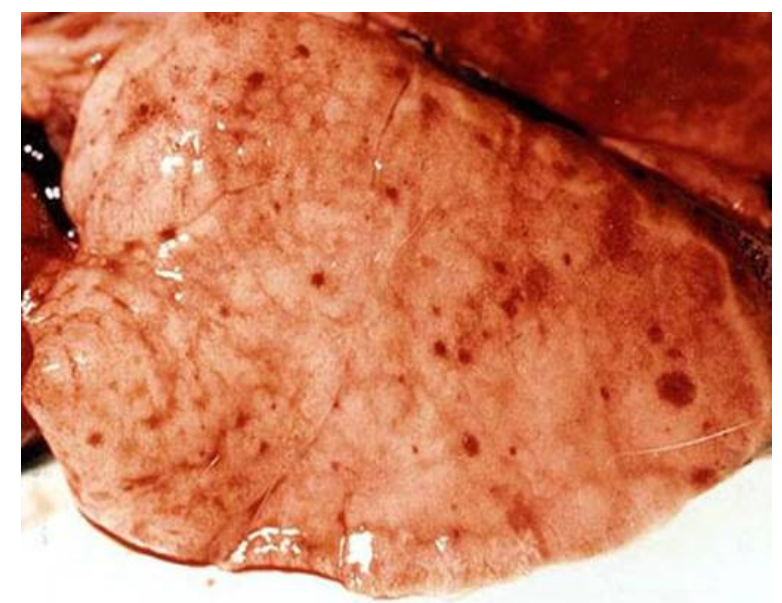

Рис. 5. Легені загиблого кроля (набряклі і мають численні крововиливи)

Шлунок: вміст кашкоподібної консистенції, буро або жовто-зеленого кольору. Слизова оболонка мала колір від сіруватого до темно-червоного, набрякла. У деяких випадках вона була каламутна, плямисто гіперемійована або всіяна крововиливами та ерозіями 3 темно-червоним дном різної величини.

Тонкий кишечник був заповнений хімусом. Слизова оболонка каламутна, набрякла, колір від сірожовтого до темно-червоного, в деяких випадках слизова дифузно гіперемована i / або пронизана множинними крапковими, смугастими і плямистими крововиливами. Гіперемія і геморагії найвиразніше виступали на верхівках складок. Кровоносні судини ін'єковані кров’ю. На брижі різко виступали деревоподібні розгалуження із гіперемійованих судин, які переходять на стінки кишечника (рис. 6). Навколо дрібних судин відзначали різко виражений діатез.

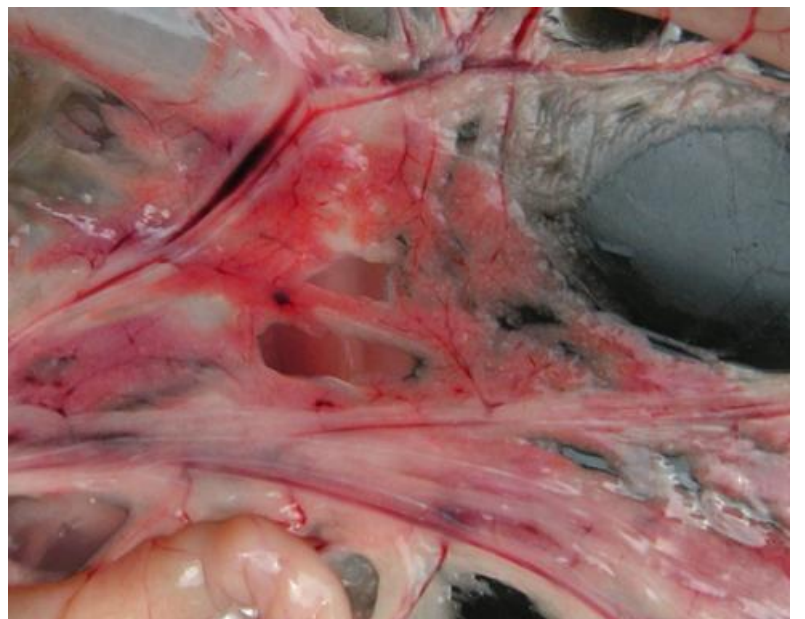

Рис. 6. Кровонаповнення судин брижі. Крововиливи в ній

Товстий кишечник: калові маси сформовані, слизова оболонка сіро-рожева, гладенька, блискуча. Кровоносні судини помірно ін'єковані кров'ю.

Печінка була від світло- або жовто-коричневого до темно-коричневого або темно-червоного з синюватим відтінком кольору, збільшена, в'яла, легко рвалася, капсула напружена. Зазвичай центральна частина 
часточок дещо темніше периферії. Печінкові часточки збільшені, межі їх дещо згладжені. 3 поверхні розрізу стікала темна кров. Під капсулою в ряді випадків чітко видно дрібні крапчасті крововиливи, зрідка смугасті (альтеративний гепатит). Часто в черевній порожнині знаходили геморагічний ексудат та вогнищеві некрози в печінці. Жовчний міхур заповнений темно-зеленою жовчю, іноді збільшений в 1,5-2 рази, слизова оболонка гладка, бархатиста.

Ураження печінки у кроликів були переважно в перипортальній областях. Кількість поодиноких або невеликих груп перипортальних гепатоцитів, включаючи випадкові клітини, були некротизовані (рис. 7).

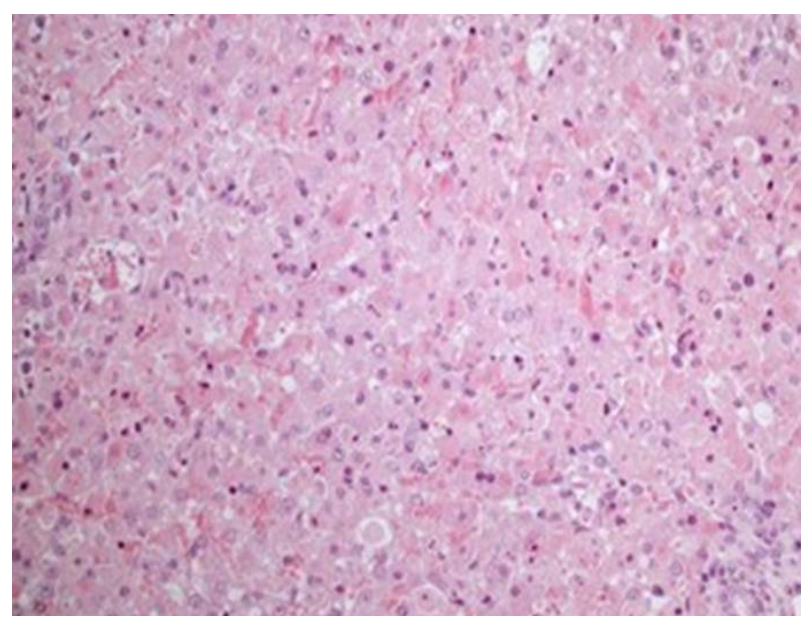

Рис. 7. Фрагмент мікроскопічної будови печінки кроля, загиблого від вірусної геморагічної хвороби (спостерігається печінково-клітинна дегенерація та некроз). Гематоксилін Ерліха та еозин. Х 200

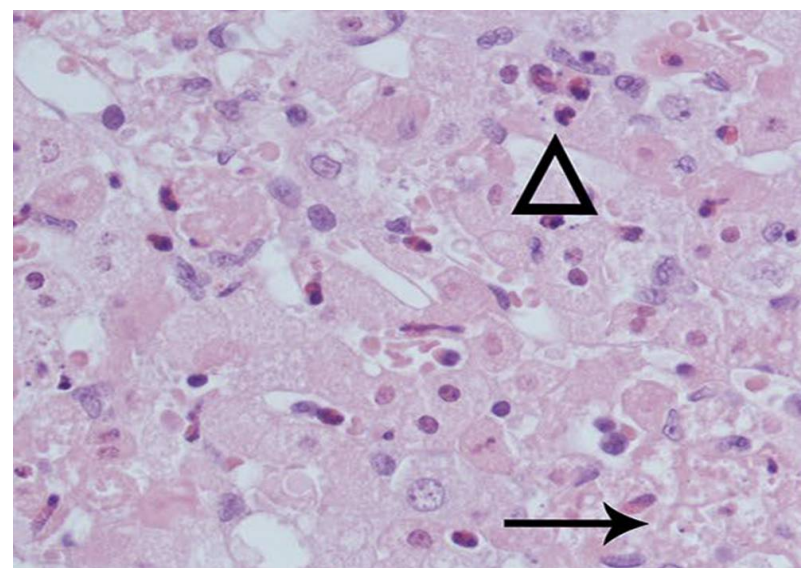

Рис. 8. Фрагмент мікроскопічної будови печінки кроля, загиблого від вірусної геморагічної хвороби

(стрілками вказані ділянки некротизованих

гепатоцитів). Гематоксилін Ерліха та еозин. X 400

Уражені гепатоцити мали гіпереозинофільну цитоплазму, що супроводжувалось каріорексисом або пікнозом ядер. На пізніх стадіях клітини або клітинні фрагменти округлювалися, зменшувалися в розмірах, часто містили пікнотичні ядерні фрагменти. Рідше уражені гіпереозинофільні гепатоцити зберігали свою форму, а ядра зникали (каріолізис). В інших частинах печінки були виявлені серед фрагментованих залишків гепатоцитів осередки некрозу і іноді кровотечі (рис. 8).

Нирки злегка збільшені в об'ємі, в’ялі, капсула помірно напружена, легко знімалася. Забарвлення на поверхні від світло- до темно-червоного або червоносинюватого. На поверхні нирок і в паренхімі зустрічали темно-червоні крапчасті або смугасті вогнища гіперемії з нечіткими краями. 3 поверхні розрізу стікала незначна кількість темної крові. Найбільш різко гіперемійовані кірковий і мозковий шари. Патологія нирок складається 3 порушення мікроциркуляції i процесів некродистрофічного характеру i зачіпає кірковий і мозковий шари.

Сечовий міхур помірно наповнений, а іноді переповнений сечею, забарвленою в жовто-солом'яний або червонуватий колір. Слизова оболонка в багатьох випадках каламутна, набрякла, в окремих випадках потовщена, гіперемійована і всіяна численними крапчастими і смугастими крововиливами.

Надниркові залози від жовтуватого до сірожовтого кольору, збільшені, в'ялі, легко рвуться при натисканні, набряклі, іноді значно набряклі, особливо в кірковій частині, яка має смугасто-строкате забарвлення. Нерідко на сіро-жовтому тлі залози видно крапчасті крововиливи.

Щитоподібна залоза від червоно-коричневого до темно-червоного кольору, збільшена, поверхня розрізу соковита, забарвлена дещо темніше, з синюватим відтінком, 3 неї стікає темна кров, іноді виявляли дрібні крововиливи.

Слинні залози збільшені в об’ємі, тістоподібної консистенції, набряклі, поверхня розрізу нерівномірно забарвлена в сіро-червоний і темно-червоний кольори, зустрічалися поодинокі крапчасті крововиливи.

Сльозні залози світлі, сіро-рожеві, м'якої консистенції.

Головний мозок часто міг бути без видимих патологічних змін, в деяких випадках кровоносні судини мозку і його оболонок ін'єковані кров'ю. Оболонки і речовина мозку набряклі. Речовина мозку волога, пружно-м'якої консистенції, межа між сірою і білою речовиною виражена чітко.

Статеві органи. У самок виявляли крововиливи в піхву, іноді - гематоми між серозним і м'язовим шарами, в ряді випадків - потовщення ендометрія, геморагічний ендометрит і вагініт. У самців макроскопічних змін нами не виявлено. У самок в матці виявляли відшарування оболонок, гіперплазію і набряк ендометрія, який виступав у вигляді складок, був інфільтрований лімфоїдними клітинами і гістіоцитами. Волокна міометрія розпушені, зустрічали діапедезні крововиливи i клітинні інфільтрати 3 лімфоцитів і гістіоцитів. Периметрій набряклий. У матковій трубі - набряк підслизового і серозного шарів (рис. 9). В яєчниках - різке кровонаповнення, набряк-тканинної оболонки фолікула (рис. 10). 


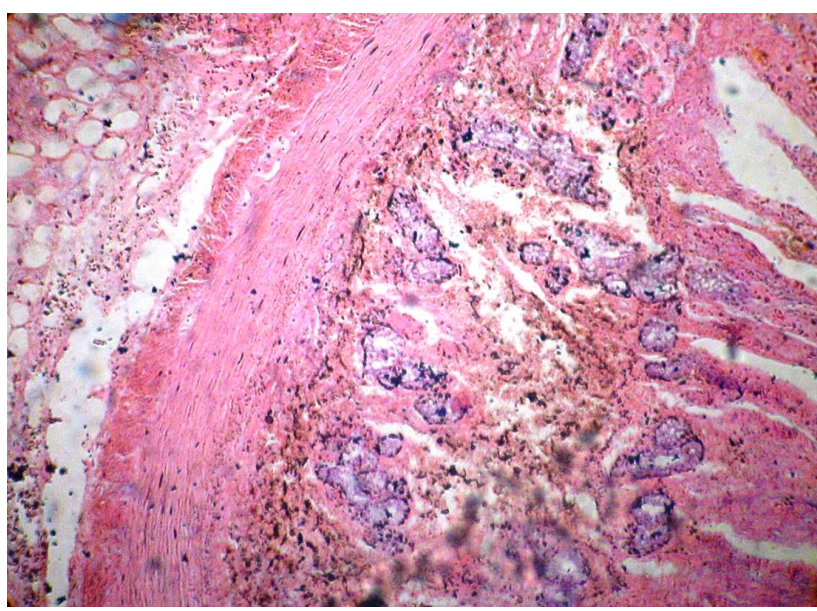

Рис. 9. Фрагмент маткової труби. Набряк підслизового і серозного шарів. Гематоксилін Ерліха та еозин. X 150

Отже, провідними патологоанатомічними змінами при вірусній геморагічній хворобі кролів є: а) венозний застій в стінках носових порожнин і трахеї (“червона трахея"); б) нерівномірне забарвлення, набряк і крововиливи в легенях; в) збільшення селезінки в 1,53 рази (слід враховувати, що селезінка може бути без видимих змін), г) в'яла печінка, вона різко кровонаповнена і дещо збільшена або світла, жовто-коричнева і в'яла (“варена печінка”); д) кровонаповнення і збільшення нирок; е) геморагії в тимусі і серці; ж) загальний венозний застій крові.

Найбільш значущі патоморфологічні зміни при постановці діагнозу на ВГХК є:

- венозний застій в стінках носових порожнин i трахеї (“червона трахея");

- нерівномірне забарвлення, набряк і крововиливи в легенях; венозна гіперемія;

- збільшення селезінки в 1,5-3 рази, ліловий, 3 характерним фіолетовим відтінком колір органу;

- набряк ретикулярної тканини і загальне збіднення лімфоцитами червоної пульпи;

- в'яла печінка, вона різко кровонаповнена і дещо збільшена 3-4 години після загибелі тварини, а також блідість і ущільнення (“варена печінка”) в більш пізні терміни;

- тотальний некроз гепатоцитів і епітелію жовчного міхура при збереженні цілісності епітелію жовчних протоків;

- крововиливи, червоно-коричневе забарвлення і збільшення нирок;

- дистрофія і некроз паренхіми;

- множинні крапчасті геморагії в тимусі і серці;

- зерниста дистрофія міокарда;

- загальний венозний застій крові, виражений особливо яскраво у великих венах і серці.

Виявлення більшості з цих змін дозволяє поставити патоморфологічний діагноз на вірусну геморагічну хворобу кролів.

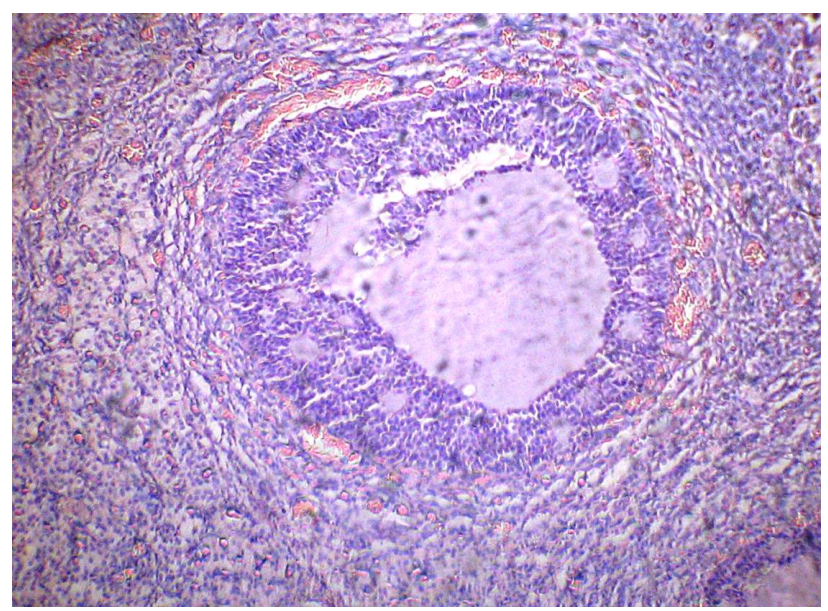

Рис. 10. Яєчник. Набряк тканинної оболонки фолікула, різке кровонаповнення. Гематоксилін Ерліха та еозин. X 150

\section{Висновки}

1. Патоморфологічні зміни при вірусній геморагічній хворобі кролів в паренхіматозних органах виражені порушенням гемодинаміки (гіперемія, набряки, крововиливи), дистрофічними і некротичними процесами в печінці (альтеративний гепатит), запальними i некротичними змінами в нирках (серозногеморагічний гломерулонефрит, тубулярний некроз епітелію ниркових канальців), серозно-геморагічною бронхопневмонією і катарально-геморагічним гастроентеритом. У головному мозку виявлено зміни, характерні для гострого негнійного лімфоцитарного енцефаліту, справжня й несправжня нейронофагія, утворення клітин-тіней, гіперхроматоз і пікноз нейронів.

2. При проведенні аутопсії слід в першу чергу звертати увагу на застійну гіперемію в трахеї, гортані, носової порожнини, набряк, почервоніння і крововиливи в легенях. В інших органах (тимус, печінка, нирки, селезінка, серце та ін.) зміни можуть бути відсутні.

3. В паращитоподібній залозі також встановлені певні зміни (вакуольна дистрофія оксифільних клітин), сльозних залозах (тромбоз судин, ядра епітеліоцитів не сприймали забарвлення) і статевих органах самок (різке кровонаповнення судин матки, крововиливи в піхву, іноді - гематоми, в ряді випадків - вагініт, ендометрит. В маткових трубах набряки підслизового і серозного шарів. У яєчниках різке кровонаповнення, набряк сполучнотканинних оболонок фолікулів).

Перспективи подальших досліджень є встановлення морфометричних показників патологічно змінених органів.

\section{References}

Bancroft, J. D., Layton, C., \& Suvarna, S. K. (2013). Bancroft's Theory and Practice of Histological Techniques. 7th edition. Churchill Livingstone: Elsevier, 672.

Cooke, B. D., \& Fenner, F. (2002). Rabbit haemorrhagic disease and the biological control of wild rabbits, 
Oryctolagus cuniculus, in Australia and New Zealand. Wildl Res, 29, 689-706. doi: 10.1071/WR02010.

Dalton, K. P., Nicieza, I., \& Abrantes, J. (2014). Spread of new variant RHDV in domestic rabbits on the Iberian Peninsula. Veterinary Microbiology, 169(1-2), 67-73. doi: 10.1016/j.vetmic.2013.12.015.

Delibes-Mateos, M., Delibes, M., Ferreras, P., \& Villafuerte, R. (2008). Key role of European rabbits in the conservation of the Western Mediterranean basin hotspot. Conserv Biol, 22, 1106-1117. doi: $10.1111 /$ j.1523-1739.2008.00993.

Delibes-Mateos, M., Ferreras, P., \& Villafuerte, R. (2008). Rabbit populations and game management: the situation after 15 years of rabbit haemorrhagic disease in central southern Spain. Biodivers Conserv, 17(3), 559-574. doi: 10.1007/s10531-007-9272-5.

Delibes-Mateos, M., Redpath, S. M., Angulo, E., Ferreras, P., \& Villafuerte, R. (2007). Rabbits as a keystone species in southern Europe. Biol Conserv, 137(1), 149-156. doi: 10.1016/j.biocon.2007.01.024.

Farnos, O., Rodriguez, D., Valdes, O., Chiong, M., Parra, F., Toledo, J. R., Fernandez, E., Lleonart, R., \& Suarez, M. (2007). Molecular and antigenic characterization of rabbit hemorrhagic disease virus isolated in Cuba indicates a distinct antigenic subtype. Arch Virol, 152(6), 1215-1221. doi: 10.1007/s00705006-0926-5.

Horalskyi, L. P., Khomych, V. T., \& Kononskyi, O. I. (2005). Osnovy histolohichnoi tekhniky i morfofunktsionalni metody doslidzhen u normi ta pry patolohii: navchalnyi posibnyk. Zhytomyr: Polissia (in Ukrainian).

Korniyenko, L. Ye., Dombrovs'kyy, O. B., Ponomar, S. I., \& Antipov, A. A. (2003). Infektsiyni ta invaziyni khvoroby kroliv. Bila Tserkva (in Ukrainian).

Le Gall-Recule, G., Zwingelstein, F., Laurent S., de Boisseson, C., Portejoie, Y., \& Rasschaert, D. (2003).
Phylogenetic analysis of rabbit haemorrhagic disease virus in France between 1993 and 2000, and the characterisation of RHDV antigenic variants. Arch Virol, 148, 65-81. doi: 10.1007/s00705-002-0908-1.

Mitro, S., \& Krauss, H. (1993). Rabbit hemorrhagic disease: a review with special reference to its epizootiology. Eur J Epidemiol, 9, 70-78. doi: 10.1007/BF00463093.

Mouss, A., Chasey, D., Lavazza, A., Capucci., L., Smid, B., Meyers., G, Rossi., C., Thiel, H. J., Vlasak, R., Ronsholt, L., Nowotny, N., McCullough, K., \& GavierWiden, D. (1992). Haemorrhagic disease of lagomorphs: evidence for a calicivirus. Vet Microbiol, 33(1-4), 375-381. doi: 10.1016/0378-1135(92)90065-2.

O'Keefe, J. S., Tempero, J., Atkinson, P. H., Pacciarini, L., Fallacara, F., Horner, G. W., \& Motha, J. (1998). Typing of rabbit haemorrhagic disease virus from New Zealand wild rabbits. N Z Vet J., 46(1), 42-43. doi: 10.1080/00480169.1998.36053.

Puggioni, G., \& Cavadini, P. (2013). The new French 2010 Rabbit Hemorrhagic Disease Virus causes an RHD-like disease in the Sardinian Cape hare (Lepus capensis mediterraneus). Veterinary Research, 44, 96-103. doi: 10.1186/1297-9716-44-96.

Serdyukov, Ya. K., \& Myrs'ka, L. R. (2014). Patomorfolohiya pechinky, nyrok ta lehen' kroliv pry virusniy hemorahichniy khvorobi. Problemy zooinzheneriyi ta veterynarnoyi medytsyny, 28(2), 637-639. URL: http://nbuv.gov.ua/UJRN/pzvm 2014 28\%282\%29 147 (in Ukrainian).

Shevchenko, A. A., \& Shevchenko, L. V. (2000). Virusnyye bolezni krolikov. Mockva: Akvarium (in Russian).

Zharov, A. V. (2000). Vskrytiye i patomorfologicheskaya diagnostika bolezney zhivotnykh. Mockva: Kolos (in Russian). 